\title{
Opór pamięci i fotografie kultury historycznej. Nekropolie Armii Czerwonej
}

Patrycja Cembrzyńska

TEKSTY DRUGIE 2020, NR 4, S. 273-295

DOI: 10.18318/td.2020.4.15 | ORCID: 0000-0001-6036-3231

Domysł Instytutu Pamięci Narodowej, aby utworzyć L Park Historyczny dla sowieckich monumentów w Bornem Sulinowie, wywołał pytania o pomniki stojące na terenach wojskowych nekropoli. Na konferencji prasowej z dziennikarzami, która odbyła się 26 czerwca 2016 roku, spotkali się zastępca prezesa IPN Paweł Ukielski oraz dyrektor Biura Edukacji Narodowej Andrzej Zawistowski'. Zawistowski tłumaczył, że w kręgu zainteresowania inicjatorów projektu są wyłącznie pomniki niezwiązane z mogiłami żołnierzy: „Nikt w Polsce nie walczy z cmentarzami". Próby ilustrowania planów IPN fotografiami nekropolii radzieckich uznał za nadużycie². Park nie powstał - okazał się zbyt kosztowny, ale dekomunizacja przestrzeni publicznej trwa.

1 IPNtv, 26 VI 2016, https://ipn.gov.pl/pl/aktualnosci/35669,IPNtvKonferencja-dot-parku-historycznego-w-Bornem-Sulinowie28062016.html (1.03.2018).

2 Por. Komunikat IPN w sprawie usuwania z przestrzeni publicznej pomników propagujących komunizm lub inny ustrój totalitarny, https:// ipn.gov.pl/pl/upamietnianie/dekomunizacja/dekomunizacjapomnikow/45390,Komunikat-w-sprawie-usuwania-z-przestrzenipublicznej-pomnikow-propagujacych-kom.html (1.04.2018) .
Patrycja Cembrzyńska - dr, absolwentka Instytutu Historii Sztuki UJ. Opublikowała książkę Wieża Babel. Nowoczesny projekt porzq̨dkowania świata i jego dekonstrukcja (Universitas 2012). Publikowała m.in. W „Didaskaliach", "Quarcie”, „Tekstach Drugich,",Przeglądzie Humanistycznym". Zajmuje się sztuką po Il wojnie światowej. W centrum jej zainteresowań znajduje się ikonografia polityczna. 
Przepisy przeforsowanej przez Prawo i Sprawiedliwość ustawy o zakazie propagowania komunizmu (Dz.U z 2016 r. poz. 744, z 2017 r. poz. 1389, 2495) nie mają zastosowania do pomników znajdujących się na terenach nekropolii oraz innych miejsc spoczynku, niemniej temat radzieckich cmentarzy wojennych zaczął dzielić lokalne społeczności - i stąd pytania dziennikarzy na konferencji prasowej IPN. Są tacy, których rażą symbole komunistyczne umocowane na mogiłach i pomnikach cmentarnych, a władzom gminnym - zwłaszcza tam, gdzie większość w lokalnych samorządach uzyskuje konserwatywna prawica - stosunkowo łatwo przychodzi zakwalifikowanie do usunięcia zdewastowanych monumentów wystawionych na cmentarzach poległym żołnierzom.

W 2009 roku władze Kostrzyna nad Odrą (woj. lubuskie) zdecydowały o przeniesieniu Cmentarza Żołnierzy Radzieckich z terenu bastionu Król na Starym Mieście na cmentarz komunalny (tłumaczono to koniecznością zapobieżenia katastrofie budowlanej) - zniknęły sierp i młot z murów twierdzy, a także górujący nad miastem obelisk z sowiecką gwiazdą.

Kontrowersje wzbudzają zwłaszcza pomniki wybudowane na mogiłach czerwonoarmistów w centrach miast. Powstaje konflikt wartości: szczątki sakralizują monument, więc jego likwidacja stanowi naruszenie kulturowego tabu, zarazem jednak obecność pomnika grobowego w przestrzeni publicznej zakłóca ją, ponieważ dochodzi do zmieszania porządku sacrum i profanum³. Taki pomnik - kilkakrotnie dewastowany (w 1946 roku wysadzony przez członków podziemia antykomunistycznego) - zbudowano m.in. w Nowym Sączu, przy al. Wolności. Nad mogiłą, na schodkowym postumencie stał łuk triumfalny, ozdobiony symbolami ZSRR oraz inskrypcjami sławiącymi radziecki oręż, całości dopełniała płaskorzeźba - umieszczono ją w przestrzeni pod łukiem - przedstawiająca dwóch żołnierzy. Pozostawienie monumentu na widoku krytykował w 2011 roku prezes PiS Jarosław Kaczyński . W 2012 roku wojewoda małopolski podjął decyzję o ekshumacji szczątków żołnierzy i przeniesieniu ich wraz z pomnikiem na kwaterę wojenną na cmentarzu komunalnym: „[...] mimo że pomnik pozostawał obiektem cmentarnym - pisze

3 D. Czarnecka „Pomniki wdzięczności” Armii Czerwonej w Polsce Ludowej i w III Rzeczypospolitej, IPN, Warszawa 2015, s. 85. Por. L.M. Nijakowski Domeny symboliczne. Konflikty narodowe i etniczne w wymiarze symbolicznym, Scholar, Warszawa 2006, s. 73.

4 S. Wrona Nowy Sącz: pomnik Armii Czerwonej zostaje przy Al. Wolności, Naszemiasto.pl, 27 listopada 2011, http://nowysacz.naszemiasto.pl/artykul/nowy-sacz-pomnik-armii-czerwonejzostaje-przy-al-wolnosci,1178167,art,t,id,tm.html (1.04.2018). 
Dominika Czarnecka - jego wydźwięk propagandowy był w świadomości obywateli na tyle silny, że funkcja komemoratywna zeszła na drugi plan"5. Ekshumacje przeprowadzono w 2015 roku, a przy okazji - jakby nie było innej możliwości - pomnik zniszczono; zmienił się w kupę gruzu.

W 2013 roku - w porozumieniu z Ambasadą Federacji Rosyjskiej w Polsce - wyburzono monumentalny obelisk na cmentarzu wojennym im. Michaiła Kutuzowa w Bolesławcu (woj. dolnośląskie). Groził zawaleniem. Obiektu nie odbudowano (jednak dodajmy od razu, że 2014 roku na cmentarzu przeprowadzono prace remontowe, które sfinansowała strona rosyjska).

Ostatni przykład: w 2016 roku z cmentarza żołnierzy radzieckich w Cybince (woj. lubuskie) usunięto tablicę z przedstawieniem Józefa Stalina - był to „ostatni Stalin" w Polce.

\section{$* *$}

Nekropolie wojskowe chroni litera prawa ${ }^{6}$ : przepisy krajowe - ustawa z 28 marca 1933 roku o grobach i cmentarzach wojennych (tekst jednolity: Dz.U. z 2017 r. poz. 681), a także międzynarodowe - przede wszystkim konwencje genewskie z 1949 roku, traktujące o ochronie ofiar wojny S- najważniejsze dokumenty międzynarodowego prawa humanitarnego ${ }^{7}$. Uregulowania I konwencji genewskiej (Konwencja o polepszeniu losu rannych i chorych w armiach czyn-

5 D. Czarnecka „Pomniki wdzięczności”..., s. 92, 446-448.

6 Zob. B. Affek-Bujalska Podstawy prawne ochrony cmentarzy, w: Ochrona cmentarzy zabytkowych: materiały szkoleniowe pracowników Państwowej Służby Ochrony Zabytków oraz materiały z konferencji Organizacja lapidariów cmentarnych Żagań-Kożuchów 20-23 czerwca 1993, red. A. Michałowski (seria: Studia i Materiały - Ośrodek Ochrony Zabytkowego Krajobrazu, Narodowa Instytucja Kultury. Cmentarze 1 [4]), OOZK NIK, Warszawa 1994, s. 27-32 oraz G. Trzaskowska Prawne aspekty istnienia cmentarzy wojennych w Polsce, w: tejże Cmentarze wojenne we Wrocławiu w latach 1939-2002, IPN, Wrocław 2008, s. 26-101.

7 Konwencje z 12 sierpnia 1949 roku miały za podstawę i zastąpiły te z 1864 (tzw. konwencja humanitarna Czerwonego Krzyża - do powstania prawnych regulacji pochówków żołnierskich doprowadziły właśnie działania Międzynarodowego Komitetu Czerwonego Krzyża), 1906 i 1929 roku. Zasady postępowania ze zwłokami żołnierzy wrogiej armii zapisano w konwencji genewskiej przyjętej w 1929 roku (obowiązywała w czasie Il wojny światowej). Jej sygnatariusze zobowiązywali się do: pochowania poległych żołnierzy wojsk przeciwnych, ustalenia tożsamości ofiar, przekazania przeciwnej stronie wykazów poległych i aktów zgonów, a po zakończeniu wojny wykazów miejsc spoczynku żołnierzy, a także utrzymania cmentarzy wojennych (w tym oznakowania mogił wojennych). Por. B. Trzaskowska Prawne aspekty..., s. 26-49 (autorka omawia również regulacje prawne opracowane na konferencji haskiej w 1907 roku dotyczące sposobu chowania jeńców wojennych). 
nych) nakładają na jej sygnatariuszy obowiązek grzebania poległych żołnierzy i poszanowania ich grobów ${ }^{8}$. Polska ustawa z 1933 roku nie określa ograniczenia czasu istnienia nekropolii wojennych, co zwykło się interpretować tak, że czas ten jest nieograniczony. Znane są jednak przypadki stosowania względem cmentarzy wojennych przepisów ustawy z 31 stycznia 1959 roku o cmentarzach i chowaniu zmarłych (tekst jednolity: Dz.U.z 2017 r. poz. 912), w której zapisano, że można przeznaczyć teren cmentarza na inny cel po upływie czterdziestu lat od ostatniego pochówku - czyli dziesięć lat wcześniej, niż stanowiła to poprzednia ustawa (z 17 marca 1932 roku). Wykorzystując lukę prawną - i łamiąc międzynarodowe i polskie prawo humanitarne - zaczęto w latach 6o. likwidować niemieckie cmentarze z okresu II wojny światowej.

Sprawę tę dość dokładnie omawia Grażyna Trzaskowska w książce Cmentarze wojenne we Wrocławiu w latach 1939-2002. Przypomina, że powojenne władze Polski nie poczuwały się do obowiązku utrzymania grobów żołnierzy niemieckich i austriackich, więc nekropolie, na których ich pochowano, nie były szczególnym przedmiotem zainteresowania urzędów miejskich. Nie przeprowadzono np. szczegółowej inwentaryzacji mogił, zarządzonej w 1946 roku w związku z pracami ekshumacyjnymi i ponownymi pochówkami ofiar wojny. Kwestię grobów żołnierzy armii niemieckiej zdominował aspekt polityczny. Żołnierzy wroga nakazano grzebać bez trumien, w mogiłach zbiorowych,

8 Dz.U. z 1956 r., nr 38, poz. 171, załącznik. W artykule 16 zapisano obowiązek ustalenia tożsamości ofiar wojny. Z kolei artykuł 17 stanowi: „Strony w konflikcie czuwać będą nad tym, aby pogrzebanie lub spalenie zwłok dokonywane indywidualnie, jeżeli okoliczności na to pozwolą, było poprzedzone przez dokładne i w miarę możności lekarskie zbadanie zwłok w celu stwierdzenia śmierci, ustalenia tożsamości i umożliwienia zdania z tego sprawy. Połowa podwójnej tabliczki tożsamości albo cała tabliczka, o ile jest pojedyncza, pozostanie na zwłokach. Zwłoki będą mogły być spalone tylko z powodu naglących wymagań higieny albo ze względów wynikających z religii zmarłych. W razie spalenia zwłok należy szczegółowo wymienić okoliczności i przyczyny tego spalenia w akcie zgonu albo w uwierzytelnionej liście zmarłych. Strony w konflikcie będą ponadto czuwać nad tym, aby zmarli byli grzebani z czcią i w miarę możności zgodnie z obrządkami religii, którą wyznawali, aby ich groby były szanowane, zgrupowane, o ile możności, podług narodowości zmarłych, należycie utrzymane i tak oznaczone, aby mogły być zawsze odszukane. W tym celu zorganizują one urzędowo na początku działań wojennych zarząd grobów dla umożliwienia ewentualnych ekshumacji, zapewnienia tożsamości zwłok bez względu na rozmieszczenie grobów i ewentualnego ich odesłania do kraju pochodzenia. Te postanowienia stosują się również do popiołów, które będą przechowywane przez zarząd grobów aż do czasu, gdy kraj pochodzenia zawiadomi ostatecznie o swych życzeniach w tej sprawie. Jak tylko pozwolą na to okoliczności, a najpóźniej po ustaniu działań wojennych, zarządy te wymienią między sobą, za pośrednictwem Biura Informacji wspomnianego w ustępie drugim artykułu 16, wykazy, podające dokładne położenie i oznaczenie grobów, jak również informacje dotyczące pochowanych tam zmarłych". 
co uniemożliwiało dokładną identyfikację szczątków. Według odmiennych zasad grzebano ofiary innych narodowości - starano się, mniej lub bardziej skutecznie, sprostać postanowieniom konwencji genewskich (zgodnie z zasadami prawa humanitarnego należy ustalić tożsamość osoby zmarłej, a także zadbać, aby groby wojenne były oznaczone w sposób umożliwiający ich odnalezienie, ponadto informacje o położeniu mogił wojennych muszą zostać przekazane zainteresowanej stronie). Po 1950 roku - w związku z powstaniem NRD i nawiązaniem przyjaznych stosunków z sąsiadem zza Odry (ich ukoronowaniem było podpisanie układu zgorzeleckiego potwierdzającego trwałość granicy na Odrze i Nysie Łużyckiej) - antyniemiecka polityka władz nieco złagodniała. Przełożyło się to na zmianę formy pochówków żołnierzy niemieckich, ale nie na opiekę nad mogiłami wojennymi ze strony państwa; nie przeciwdziałano dewastacjom cmentarzy. Może to wskazywać, że już wtedy przeznaczono je do likwidacji - ułatwiły ją, jak już wspomniałam, uregulowania prawne z 1959 roku’.

Podsumowując politykę polskich władz wobec grobów żołnierzy armii wroga, Trzaskowska stwierdza, że w zasadzie zmierzała ona do jednego celu: „«wymazania» faktu ich istnienia ze świadomości narodowej Polaków”10. Uważano, że roztoczenie opieki nad niemieckimi cmentarzami wojennymi mogłoby doprowadzić do zatarcia różnic między agresorem a ofiarami i obrońcami - tym samym nie zdobędzie to akceptacji społecznej. W konsekwencji stan zachowania cmentarzy katastrofalnie się pogorszył. Nie zabezpieczono środków budżetowych na zabiegi utrzymaniowe i pielęgnacyjne; nekropolie zaczęły zarastać chwastami. Tereny cmentarne pozostawiono bez dozoru, co ułatwiło ich dewastację. Indywidualne i grupowe inicjatywy społeczne na rzecz ochrony mogił niemieckich uznano za bezprawne. Ponadto strona polska - wbrew powinności wynikającej z podpisanych przez nasz kraj konwencji genewskich (z czego doskonale zdawano sobie sprawę) - nie była zainteresowana współpracą z niemieckimi organizacjami humanitarnymi poszukującymi grobów wojennych i ograniczała im dostęp do informacji.

Aby odeprzeć argument niemieckich władz i opinii publicznej o braku opieki nad cmentarzami, podejmowano działania pozorujące, wszakże do poprawy stanu zachowania mogił nie mógł przyczynić się przyjęty w 1958 roku państwowy program porządkowania nekropolii na ziemiach zachodnich i północnych; fundusze, które przeznaczono na ten cel, były zdecydowanie

9 G. Trzaskowska Prawne aspekty..., s. 60, 63, 68, 72-73. 
niewystarczające - nie można tego nazwać inaczej jak propagandą. Cmentarze zaczęto zamykać. Tłumaczono się niedoborami powierzchni grzebalnej oraz zasłaniano troską o miejsca pochówków i planowane renowacje obiektów cmentarnych. Drażliwa kwestia mogił niemieckich została uregulowana dopiero w latach 9o. ubiegłego wieku; sprawę opieki nad grobami porządkuje przede wszystkim polsko-niemiecki traktat o dobrym sąsiedztwie z 17 czerwca 1991 roku".

Zamykając wątek niemieckich cmentarzy wojennych, chcę zwrócić uwagę, że zupełnie inaczej upamiętniano żołnierzy „bratniego i wyzwolicielskiego narodu radzieckiego". Różnica bierze się stąd, że opieka nad ich mogiłami miała w czasach Polski Ludowej znaczenie propagandowe, służyła zacieśnianiu więzi radziecko-polskich. Szacuje się, że na ziemiach polskich poległo około 500 (do 60o) tysięcy żołnierzy czerwonej gwiazdy. Liczbę grobów czerwonoarmistów komuniści wykorzystywali do legitymizacji powojennego porządku politycznego i uzasadniali nimi obecność wojsk sowieckich w Polsce $^{12}$. Nekropolie radzieckie stały się państwowymi miejscami kultu.

\section{***}

Inwentaryzacja wojennych miejsc pochówku, przeprowadzona w latach 1945-1947, wykazała bardzo zły stan techniczny grobów czerwonoarmistów; cmentarze były budowane pośpiesznie i niewłaściwie lokalizowane.

11 Tamże, s. 88-94, 97-98, 99-101. Nadal jednak wiele kontrowersji wzbudzają groby osób oskarżanych o zbrodnie wojenne. W 2003 roku Artur Guzicki opisywał w "Polityce” dwie wsie pod Wrocławiem - Miłoszyce i Nadolice Wielkie - które "łączy asfaltowa szosa" $\mathrm{i}$ "dzieli historia pochowana na cmentarzach". W Miłoszycach, gdzie jesienią 1943 roku Niemcy założyli obóz pracy przymusowej (Arbeitslager Fünfteichen, filia KL Groß-Rosen), znajduje się cmentarz ofiar hitleryzmu. W Nadolicach Wielkich, gdzie powstał Park Pokoju, złożono szczątki kilkunastu tysięcy żołnierzy niemieckich, którzy zginęli w czasie II wojny światowej na Dolnym Śląsku i Opolszczyźnie; pochowano tu żołnierzy Wehrmachtu i Waffen SS, w tym także strażników obozu w Miłoszycach, m.in. komendanta obozu Karla Stoppla. Guzicki przerwał stan powszechnej niewiedzy. Przebiegu dyskusji, która rozgorzała po publikacji artykułu, nie będę jednak w tym miejscu szczegółowo omawiać - dość wspomnieć żądania, żeby z Parku Pokoju usunąć polskie symbole państwowe i przekształcić go w zwykłą nekropolię. Zob. A. Guzicki Dwa cmentarze, „Polityka” 2003 nr 46, s. 92-93; S. Sieradzki Polska czciSS, „Wprost” 2004 nr 4, s. 6; S. Sieradzki Polski panteon SS, „Wprost" 2004 nr 6, s. 26-28, www.wprost.pl/tygodnik/55713/polski-panteon-ss. html (1.04.2018); W. Suleja Pamięć nie dla zbrodniarzy, "Rzeczpospolita” 2004 nr 46 (26 II 2004), s. A3; IPN Przegląd mediów z 26 lutego 2004 roku: https://ipn.gov.pl/pl/dla-mediow/media-o-ipn/14126,PRZEGLAD-MEDIOW-26-lutego-2004-r.html (1.04.2018). 
Komunistyczne władze (Trzaskowska zwraca uwagę na tempo działań Komitetu Centralnego PZPR), potwierdzając wolę wzmocnienia stosunków dwustronnych, zdecydowały się przeprowadzić kosztowną akcję komasacji cmentarzy: prace ekshumacyjne i budowę (rozbudowę/przebudowę) nekropolii Armii Czerwonej ${ }^{13}$.

Niestety, uprzywilejowana pozycja ZSRR nie w pełni przełożyła się na respektowanie zapisanych w prawie humanitarnym zasad pochówków ofiar wojny. Przeprowadzając ekshumacje, nie dołożono wszelkich starań, aby zidentyfikować tożsamość ofiar i zabezpieczyć ich dane osobowe, co zepchnęło w anonimowość groby żołnierzy Armii Czerwonej ${ }^{14}$.

Porządkowanie terenów cmentarnych zakończyło się właściwie dopiero w latach 6o. (proces identyfikacji nazwisk poległych i uporządkowanie stanu ewidencyjnego grobów trwały jeszcze dłużej). Nadzwyczajny przegląd stanu nekropolii został przeprowadzony w związku ze zbliżającą się 50. rocznicą rewolucji październikowej ${ }^{15}$, przeprowadzono wtedy kompleksowe prace renowacyjne i modernizacyjne (zostały w całości sfinansowane $\mathrm{z}$ budżetu państwa): alejki wysypano żwirem, mogiły obramowano krawężnikami $\mathrm{z}$ betonu lub kamienia, posadzono żywopłoty, wykonano tablice $\mathrm{z}$ danymi osobowymi poległych.

Niektóre nekropolie, zwłaszcza cmentarze oficerskie, wyróżnia wysoki poziom rozwiązań urbanistycznych i architektonicznych. Wspomnę tylko - to podręcznikowy przykład ${ }^{16}$ - największy pod względem zajmowanej powierzchni - wraz z zielenią zajmuje 19,2 ha - Cmentarz Mauzoleum Żołnierzy Radzieckich przy ul. Żwirki i Wigury w Warszawie, zaprojektowany przez Bohdana Lacherta i Władysława Niemirskiego, z którymi współpracowali rzeźbiarze Jerzy Jarnuszkiewicz i Stanisław Lisowski.

Schemat urbanistyczny nekropolii odwołuje się do koncepcji „miasta idealnego", charakteryzuje się symetrią osiową oraz geometrycznym uporządkowaniem sektorów mogił. Najważniejszy akcent plastyczny założenia

13

14 s. 86.
G. Trzaskowska Prawne aspekty..., s. 73-77.

Tamże, s. 101.

Tamże, s. 76-77. Por. B. Affek-Bujalska Groby żołnierzy armii radzieckiej poległych w Polsce w II wojnie światowej, Biuletyn ROPWiM „Przeszłość i Pamięć” 1999 nr 1. Autorka omawia też obecny stan utrzymania sowieckich cmentarzy i kwater, uwzględniając aspekty prawne i finansowe opieki nad nimi (s. 45-47).

Por. A.K. Olszewski Dzieje sztuki polskiej 1890-1980, Wydawnictwo Interpress, Warszawa 1988, 
stanowi kilkunastometrowy obelisk wykonany z granitu. Po obu stronach obelisku znajdują się monumentalne rzeźby alegoryczne posadowione na postumentach w kształcie sarkofagów: Bohaterstwo (Jarnuszkiewicza) i Ofiarność (Lisowskiego). Wejście na aleję główną flankują przeskalowane kamienne skrzynie sarkofagowe z płaskorzeźbami przedstawiającymi wyzwolenie ziem polskich spod okupacji niemieckiej. Po obu stronach alei usytuowano w trzech rzędach mogiły oficerów. Pola grzebalne na groby szeregowych żołnierzy zaprojektowano $\mathrm{w}$ formie dwóch prostokątów, usytuowanych pod kątem względem części centralnej. Całość stanowi urzeczywistnienie założeń realizmu socjalistycznego. Twórcy nekropolii odwołali się do najlepszych wzorców klasycznych. Pragnąc sugestywnie przedstawiać bohaterstwo żołnierzy radzieckich, Jarnuszkiewicz i Lisowski nawiązują do rzeźb starożytnych, m.in. do Umierającego gala z kolekcji Ludovisi, a także na socrealistyczną modłę przetwarzają motyw piety.

Poprzez politykę grobów, wyrażającą się uprzywilejowaniem spraw ochrony oraz utrzymania w należytym stanie cmentarzy radzieckich, wyrażano „wdzięczność dla Związku Radzieckiego za wyzwolenie narodu polskiego" (by użyć propagandowej formułki z czasów słusznie minionych). Wspieraniem organów administracji państwowej i koordynowaniem prac w zakresie opieki nad grobami zajmowała się utworzona 2 lipca 1947 roku Rada Ochrony Pomników i Męczeństwa (od 7 kwietnia 1949 roku działająca pod nazwą Rada Ochrony Pomników Walki i Męczeństwa, zniesiona 1 sierpnia 2016 roku - jej kompetencje przejęły MKiDN i IPN ${ }^{17}$ ). Rada opiniowała projekty pomników, nadzorowała ich budowę, współorganizowała uroczystości upamiętniające poległych ${ }^{18}$. Wszelako - zarówno ze względu na rachunek kosztów, jak i funkcję socjalizacyjno-wychowawczą - w opiekę nad mogiłami żołnierzy komunistyczne władze starały się włączyć całe społeczeństwo, organizując np. czyny społeczne z udziałem młodzieży i robotników. Towarzyszyły one przede wszystkim przygotowaniom do obchodów rocznicowych, takich jak: Dzień Armii Czerwonej i Marynarki Wojennej (23 lutego) czy Święto Rewolucji Październikowej (7 listopada) ${ }^{19}$.

Art. 10, 11 i 12 Ustawy z dnia 29 kwietnia 2016 roku o zmianie ustawy o Instytucie Pamięci Narodowej - Komisji Ścigania Zbrodni przeciwko Narodowi Polskiemu oraz niektórych innych ustaw (Dz.U. z 2016 r. poz. 749).

19 Tamże, s. 96-97. 
***

ROPWiM prowadziła działalność wystawienniczą, a także edukowała i popularyzowała historię „męczeństwa bratnich narodów”.Z inicjatywy ROPWiM wydano, między innymi, album Towarzyszom Broni 1944-1945 (I wyd.: 1970, II wyd.: 1974) z fotografiami przedstawiającymi cmentarze Armii Czerwonej oraz ustawione w przestrzeni publicznej pomniki ku czci radzieckich bohaterów.Zdjęcia pokazują, jak polsko-radziecki sojusz kształtuje przestrzeń i ikonosferę polskich miast. Biorąc pod uwagę,że niektóre z pomnikizaprezentowane w albumie zostały zburzone, publikacja stanowi cenny dokument epoki. Powstała, aby kształtować postawy społeczne, na jej przykładzie dobrze widać, jak propaganda korzysta z fotografii, a także jak posługuje się słowem, by wzmocnić przekaz wizualny.

Album rozpoczyna się wierszem Władysława Broniewskiego Pokłon rewolucji październikowej o przyjaźni niegdyś zwaśnionych narodów ${ }^{20}$. O niej traktuje także zamieszczony na następnej stronie płomienny wstęp Janusza Wieczorka. Przewodniczący ROPWiM pisze, jak to „błyskawiczne działania wojsk radzieckich uchroniły od zniszczenia przez hitlerowców wiele naszych miast i rejonów”, jak to „każdego dnia ludność naszego kraju witała z wdzięcznością żołnierzy radzieckich". To, co Broniewski zamknął w metaforze o porosłej „kwiatami ziemi krwi²1 i miłości”, Wieczorek powtarza językiem apelu poległych z elementami odezwy partyjnej - walka ramię w ramię i wspólnie przelana krew scementowały braterstwo polsko-radzieckie: „Nigdy nie zginie wśród Polaków pamięć o poległych wyzwolicielach - żołnierzach Armii Czerwonej". By nie zginęła, wzniesiono w całym kraju pomniki i obeliski upamiętniające radzieckich bohaterów: „Niech o wdzięczności naszego narodu, jego pamięci o tych, którzy ofiarą własnego życia zapłacili za zwycięstwo przypomina ten album. Poświęcamy go Towarzyszom Broni! Wieczna chwała żołnierzom Armii Radzieckiej poległym w walce z faszyzmem" ${ }^{22}$.

20 "Kłaniam się mogiłom Stalingradu, /mogiłom Berlina i Moskwy - / my, po latach stalowego gradu, na nich w przyszłość mościmy mosty. / Na rosyjskiej i na polskiej ziemi, / na ziemi krwi i miłości, / rosną kwiaty / - my je znajdziemy - / pośród poległych kości". Zob. R. Matuszewski Poezja Władysława Broniewskiego w latach 1939-1954 " Pamiętnik Literacki” 1954 t. 45, nr 4, S. 477-503.

21 Na nadużywanie słowa „krew" w ówczesnym dyskursie publicznym zwrócił już uwagę Marcin Zaremba, więc pomijam ten wątek - zob. M. Zaremba Wielka Trwoga. Polska 1944-1947. Ludowa reakcja na kryzys, Znak-Instytut Studiów Politycznych Polskiej Akademii Nauk, Kraków 2012, s. $493-945$.

22 Towarzyszom Broni 1944-1945, oprac. graf. M. Hibner, Krajowa Agencja Wydawnicza RSW Prasa.Książka·Ruch, Warszawa 1974. Fotografie wykonali: Henryk Hermanowicz, Teodor Hermań- 
Pamiętanie, jak podkreśla Aleida Assmann, wymaga stworzenia systemu zabezpieczeń - przede wszystkim wsparcia instytucjonalnego i mediów magazynowania - należy do nich fotografia ${ }^{23}$. Warto też zauważyć, że pamiętamy najlepiej to, co dociera do naszych umysłów przez oczy ${ }^{24}$.W albumie znalazły się zdjęcia wykutych w kamieniu albo odlanych w brązie dowodów socjalistycznej przyjaźni. Za pośrednictwem tej kolekcji fotograficznej społeczeństwo miało przyswoić sobie - dosłownie: uczynić swoim - przedstawione w albumie artefakty i zawarty w nich przekaz ideologiczny. Dostarczając przeżyć estetycznych, publikacja uczy właściwego stosunku do nich. Zakłada się tutaj, że pamiętać to dochowywać wierności („wieczna chwała”). Ten album to coś więcej niż fotograficzny inwentarz. Fotografia służy powieleniu obiektów, zbiera w jedno to, co rozproszone, i czyni ogólnodostępnym. Kumulowanie i powielanie wzmacnia przekaz. Fotografii przypada rola protezy pamięci oraz środka propagandy. Za jej pomocą wpaja się zarówno wartości moralne i polityczne, jak i wzory estetyczne. Przede wszystkim socrealizm, choć album dowodzi również, że sztuka propagandowa okresu komunizmu, wbrew obiegowej opinii, nie była jednorodna; zdjęcie pomnika wdzięczności Armii Czerwonej w Olsztynie według projektu Xawerego Dunikowskiego oraz zdjęcie żelbetowego monumentu na cmentarzu wojennym w Szczecinku, zaprojektowanego przez Melchiora Zapolnika i Ryszarda Grodzkiego, pokazują, jak eksperymenty formalne ożywiały sztywne ideologiczne dogmaty ${ }^{25}$.

Heroiczny temat - śmierć żołnierzy na polu chwały - otrzymuje okazałą oprawę rzeźbiarsko-architektoniczną, a na zdjęciach pokazano to, co godne szczególnego uwydatnienia. Wyraźnie wyeksponowano szeregi jednakowych steli, przypominających wojsko w szyku bojowym - widać charakterystyczną unifikację mogił i znaków mogilnych (czerwona gwiazda) ${ }^{26}$. Fotografowie

czyk, Adam Koczkowski, Zdzisław Postępski, Zdzisław Śliwian, Czesław Woźny, Feliks Zwierzchowski.

23 A. Assmann Kanon iarchiwum, przeł. A. Konarzewska, w: tejże Między historiq̨ a pamięcią. Antologia, red. nauk. i posł. M. Saryusz-Wolska, Wydawnictwa UW, Warszawa 2016, s. 76 oraz tejże Cztery formy pamięci, przeł. K. Sidowska, tamże, s. 55.

F.A. Yates Sztuka pamięci, przeł. W. Radwański, posł. L. Szczucki, PIW, Warszawa 1977, s. 16. Wyraźna zmiana nastąpiła po śmierci Stalina (1953), kiedy socrealizm przestał być stylem obowiązującym. 
starają się wydobyć walory krajobrazowe przestrzeni cmentarnej, pokazać każdą ciekawą perspektywę widokową, którą wytyczyli architekci. Zdjęcia służą intensyfikacji odbioru form architektonicznych i rzeźbiarskich.

Pomieszczone w albumie krajobrazy mają zarówno wymowę informacyjno-topograficzną, jak i estetyczno-emocjonalną - są dalekim echem XVII-wiecznych pejzaży klasycystycznych ${ }^{27}$.

Subtelny patos przenika cmentarz przy ul. Żwirki i Wigury w Warszawie. Fotograf uwydatnia geometryczny porządek miejsca. Po środku - obelisk; pokrywa się z osią symetrii obrazu i dzieli go na dwie części w ten sposób, że stanowią swoje lustrzane odbicie (widać bliźniacze rzeźby figuralne na sarkofagach w jednakowej odległości, po obu stronach obelisku). Tu wszystko jest liczbą, ma swoje metrum i rytm - jedynie chmurne niebo nie liczy się z prawami geometrii. Wieje żałobną melancholią, wytworny ład zostaje zmącony. W obelisku jednakże, wokół którego cała ta historia się rozwija, mieszka słońce ${ }^{\mathbf{2 8}}$, a to jemu wszystkie formy zawdzięczają przecież swoje istnienie. Fotografowi udaje się złączyć śmierć z obrazem pełnym pogody. Jak zwizualizować stan ataraksji? Właśnie tak, odebrać cmentarz ciemności, składając równocześnie hołd siłom ładu i porządku²9. Można też jednak pokazać architekturę grobową pośród drzew i krzewów (skądinąd nie przypadkiem najpiękniejsze cmentarze projektuje się jako założenia parkowe); prawem kontrastu zestawić milczące kamienie z bogactwem tekstur żyjących form roślinnych. Na kilku fotografiach żołnierskie nekropolie ukazują się nam jako malownicze gaje pamięci z mogiłami wkomponowanymi w przyrodę. Tutaj alegoryzuje się żołnierską śmierć przez odwołanie do mitu o Elizjum, nie chodzi jednak o życie pozagrobowe, ale o wieczną pamięć potomnych ${ }^{30}$.

Właściwie tylko w jednym przypadku bardzo pobieżne potraktowano warstwę informacyjną obrazu. Chodzi o zdjęcie zrobione na cmentarzu wojskowym w Gorzowie Wielkopolskim, przedstawiające pomnik-obelisk wzniesiony ku czci żołnierzy 5 Armii 1 Frontu Białoruskiego, poległych w walkach o wyzwolenie Ziemi Gorzowskiej.To fotografia, która przemawia przede wszystkim do wyobraźni. Monument sfotografowano z żabiej perspektywy, pod światło,

27 Zob. J. Woźniakowski Góry niewzruszone. O różnych wyobrażeniach przyrody w dziejach nowożytnej kultury europejskiej, Znak, Kraków 1995 (zwł. rozdz. Góry klasyczne - tamże zob. również rozważania na temat wzniosłości).

Wedle tradycji, obeliski to obiekty kultu solarnego. 
co potęguje wrażenie ogromu. Naszym oczom ukazuje się jakiś nadzwyczajny, majestatyczny monolit, rzucający wieki cień. Detali plastycznych pomnika nie widać, ale nie one są istotne - obelisk wystrzeliwuje w niebo i rozbłyska u wierzchołka słoneczną gwiazdą - zdaje się dotykać słońca. Za sprawą prostej fotograficznej sztuczki przestrzeń nabiera nowych znaczeń i ewokuje symboliczne sensy. Udaje się stworzyć atmosferę wzniosłości. Zwykło się uważać, że dochodzi ona do głosu tam, gdzie wykracza się poza zwykłą miarę. Jako wzniosłe odbieramy więc formy potężne, strzeliste, sztywne i kanciaste, wzniosłość lubi układy pionowe oraz linie proste, pomagają ją również wywołać gwałtowne kontrasty światła i cienia - jak na tym zdjęciu. Na pomnik upamiętniający determinację żołnierzy walczących o pokój i komunizm fotograf każe nam patrzeć przez pryzmat walki światła i ciemności. W ten sposób podkreśla polityczną doniosłość wyzwoleńczej ofensywy. Słoneczna gwiazda świecąca na szczycie obelisku przypomina, że duch rewolucji płonie.

\section{***}

Jednak płomień rewolucji przygasł, komunizm upadł. Obecnie na wygląd nekropolii sowieckich niekorzystnie wpływa brak środków finansowych (utrzymaniem cmentarzy wojskowych zajmują się gminy; koszty opieki ponosi wprawdzie skarb państwa, ale gminy partycypują w kosztach konserwacji). Niemało kosztuje naprawa małej architektury: mauzoleów, gloriet, obelisków i rzeźb figuralnych dekorujących nekropolie. Kosztują remonty nagrobków, dróg, pielęgnacja zieleni. Im większa ranga obiektu, a tym samym im bogatszy wystrój architektoniczno-rzeźbiarski, tym więcej elementów plastycznych wymagających prac konserwatorskich. Kosztowne jest również usuwanie szkód powstałych wskutek wandalizmu i kradzieży (głównie elementów metalowych) $)^{31}$.

Uroczystości propagandowych nad grobami żołnierzy Amii Radzieckiej już się nie organizuje, co nie pozostaje bez wpływu na stan zachowania cmentarzy. Zmienia się również społeczne postrzeganie sowieckich nekropolii.

Po 1989 roku dozwolone stało się publiczne mówienie o „dwóch wrogach, którzy napadli na Polskę"32. Upowszechniała się wiedza na temat

B. Affek-Bujalska, Grobyżołnierzy armii radzieckiej... 
przemilczanych dotąd faktów ze sfery polsko-radzieckich stosunków w czasie wojny ${ }^{33}$, takich jak współodpowiedzialność Stalina za jej wybuch, zbrodnia katyńska, nieudzielenie pomocy powstaniu warszawskiemu, los Polaków na terenach zajętych przez ZSRR (przesiedlenia, zsyłki do łagrów) i last but not least zachowanie Armii Radzieckiej po wejściu na ziemie polskie: gwałty, grabieże mienia, które złożyły się na traumę „wielkiej trwogi” - wedle sformułowania Marcina Zaremby ${ }^{34}$.

Zmiany w społecznym postrzeganiu cmentarzy Armii Czerwonej są uwarunkowane potrzebą określenia się na nowo - po odzyskaniu wolności w 1989 roku - wobec II wojny światowej, wiążą się z rewizją peerelowskich narracji o wojnie i z konfliktem na froncie symbolicznym, towarzyszącym odkłamywaniu historii i nawrotom pamięci o minionych wydarzeniach. Zbrodnie wojenne, podkreśla Trzaskowska, nie były wyłączną domeną niemiecką: „Zagadnienie odpowiedzialności armii radzieckiej za popełnione czyny wojenne jest jednym $\mathrm{z}$ aspektów społecznego postrzegania ich mogił z ostatniej wojny światowej" ${ }^{35}$.

Marcin Kula zwraca uwagę, że sprawy, miejsca i symbole istotne dla innych niż własna grupa pamięta się zawsze przez pryzmat kontaktów, dobrych albo złych, z własną społecznością. Najtrudniej, powiada Kula, przychodzi zachować nośniki pamięci istotne dla tej grupy, którą uznajemy za wrogą - symptomatyczne są właśnie nieporozumienia towarzyszące budowie i dotyczące utrzymania cmentarzy wojennych ${ }^{36}$. Przypadek cmentarzy Armii Czerwonej jest o tyle wyjątkowy, że jeszcze do niedawna „wróg" funkcjonował w oficjalnym dyskursie jako „przyjaciel”.

$\mathrm{Na}$ społeczne postrzeganie cmentarzy wojennych wyraźnie rzutuje polityka rozliczania się z komunizmem. Nie bez znaczenia są próby politycznego rozgrywania sprawy „powojennej niewoli komunistycznej” przez prawicę, często skutkujące upraszczaniem dziejów oraz utrwalaniem stereotypów. W historii hańby i chwały, opowiadanej z pozycji antykomunistyczno-narodowych, żołnierze radzieccy z bohaterów i sojuszników stają się wrogami-okupantami - roztapiają się w niezróżnicowanej

M. Kula Selektywność pamięci, w: tegoż Między przeszłościq̨ a przyszłością. O pamięci, zapominaniu i przewidywaniu, Poznańskie Towarzystwo Przyjaciół Nauk, Poznań 2004, S. 110-113.

M. Zaremba Wielka Trwoga...

G. Trzaskowska Prawne aspekty..., s. 48. 
masie bolszewików i jako podmiot zbiorowy reprezentują winy sowieckiego hegemona.

Honorowanie pamięci o żołnierzach Armii Czerwonej poległych na ziemiach polskich staje się trudne w sytuacji, gdy komunistyczna przeszłość zaczyna dzielić społeczeństwo. Rzeczywistość polityczna zdominowana została przez narrację antykomunistycznego braterstwa (choć przecież jego pojednawcza moc jest wątpliwa) $)^{37}$. Rozrachunek z epoką komunizmu staje się obroną narodowego honoru, stawianiem Polaków przed koniecznością udowadniania, że z komunizmem nie mieli i nie chcą mieć nic wspólnego, i nie będą się przeglądać w jego krzywych zwierciadłach (wprowadza się działania zapobiegawcze, taki właśnie charakter ma w moim przekonaniu ustawa o zakazie propagowania komunizmu, regulująca kwestie usuwania „pomników wdzięczności”38).

Znane są przypadki bezczeszczenia mogił żołnierzy Armii Czerwonej. Antykomunistyczna polityka Prawa i Sprawiedliwości - prawicowej partii wykorzystującej i podsycającej antyrosyjskie fobie części społeczeństwa wydaje się ośmielać do działań tego rodzaju.

Nasilenie ataków na radzieckie pomniki i cmentarze dało się zaobserwować po katastrofie samolotu prezydenckiego w Smoleńsku w 2010 roku. Tereny niektórych nekropolii zmieniły się w poligon polityczny, gdzie grupa rzekomo wykluczona z oficjalnej debaty komentowała „zdradziecką" (antypolską) politykę koalicji rządzącej i walczyła o „prawdę”.

W kwietniu 2010 roku na tablicy pamiątkowej na cmentarzu radzieckim w poznańskiej Cytadeli pojawiły się rysunki sierpa, młota, swastyki oraz napis „Katyń”.W 2011 roku w Gliwicach, po uroczystościach ku czci ofiar katastrofy smoleńskiej, na bramie wejściowej cmentarza, na którym pochowano żołnierzy radzieckich, można było przeczytać: „Tu gnije żołnierz radziecki, który mordował nas w Katyniu"39. Wiele zamieszania wywołały wydarzenia z listopada 2010 roku, kiedy to na cokole pomnika znajdującego się na Cmentarzu Mauzoleum Żołnierzy Radzieckich w Warszawie umieszczono napis: „Tusk chcemy prawdy o Smoleńsku”. Także w marcu 2017 roku doszło do dewastacji nekropolii przy ul. Żwirki i Wigury. Na schodach centralnego

\footnotetext{
Por. P. Czapliński Polska do wymiany..., rozdz. PRL i oczyszczanie nowoczesności.

Pełna nazwa: Ustawa o zakazie propagowania komunizmu lub innego ustroju totalitarnego przez nazwy jednostek organizacyjnych, jednostek pomocniczych gminy, budowli, obiektów i urzq̨dzeń użyteczności publicznej oraz pomniki (Dz.U. z 2016 r. poz. 744, z 2017 r. poz. 1389, 2495).
}

Więcej zob. D. Czarnecka „Pomniki wdzięczności”..., s. 344. 
obelisku i ułożonych wokół płytach pojawiły się rysunki przedstawiające swastykę i czerwone odciski stóp na tle flagi państwowej Izraela; swastykę wpisano w niebieską gwiazdę Dawida, czerwone odciski stóp umieszczono po bokach flagi. Antysemickie znaki i napisy pojawiały na terenie cmentarza już wcześniej.

Symbole nazistowskie to zapewne nawiązanie do sowiecko-niemieckiej współpracy w okresie 1939-1941. W tym kontekście, jak podaje Czarnecka w książce o monumentach wystawionych Armii Czerwonej, swastyki i symbole SS pojawiały się na grobach żołnierzy radzieckich już w okresie PRL-u, przede wszystkim w latach 8o., kiedy przestano ukrywać, że oprócz 1 września, był też 17 września ${ }^{40}$. Jednak by w pełni zrozumieć opisywane incydenty, trzeba uwzględnić „potoczne poglądy na historię” - wedle określenia Barbary Szackiej. Dość powiedzieć, że mamy do czynienia z pewnym nadmiarem poglądów w stosunku do posiadanych zasobów rzetelnych informacji ${ }^{41}$.

Podążając tropem Marcina Zaremby, weźmy pod uwagę, że strach przed tym, co „idzie ze Wschodu", wszedł w krwiobieg kultury polskiej wraz z wojną 1920 roku, umocniły go tajemnice Lasu Katyńskiego (1940) - to właśnie one przypomniały o sobie w teoriach spiskowych powstałych wokół katastrofy smoleńskiej (stąd: „Tusk chcemy prawdy o Smoleńsku” na grobach żołnierzy) - ugruntowały „wypaczenia” okresu stalinizmu, a potem stan wojenny z jego „wejdą czy nie wejdą?”. Strach ten utkwił w świadomości Polaków, ukształtował społeczną pamięć przeszłości, zakorzenił się w życiu codziennym ${ }^{42}$; łatwo budzą go wypowiedzi prawicowych polityków. W pamiętnym „roku katastrofy” dał o sobie znać i związał się z drugim „potocznym” strachem - który także jest rozgrywany politycznie - strachem przez Żydami, zgłaszającymi się po swoje mienie i rzekomo mącącymi w polityce ${ }^{43}$.

Wplatanie wątku żydowskiego do walki z "czerwonymi” zaczęło się w dwudziestoleciu międzywojennym. Narodził się wtedy stereotyp żydokomuny ${ }^{44}$ - negatywnego bohatera wyobraźni społecznej aż do dzisiaj. To, jak

40 Tamże, s. $162,165$.

41 B. Szacka Miejsce historii w świadomości współczesnego człowieka, "Kwartalnik Historyczny” LXXX 1973, s. 360. Por. tejże Świadomość historyczna (Wnioski z badań empirycznych), "Studia Socjologiczne" $1977 \mathrm{nr} 3$, s. 67.

M. Zaremba Wielka Trwoga... - nie przypadkiem Zaremba kończy swoją książkę rozważaniami na temat "strachu przed Rosją i jej zbrojnym ramieniem" i "strachu przed Żydami" (s. 647).

Na temat genezy tego stereotypu zob. tamże, rozdz. Bolszewickie piekło i Chimera żydokomuny. 
się zdaje, właśnie do „potomków żydokomuny” - rzekomo rządzących Polską - piją autorzy antysemickich graffiti na cmentarzu żołnierzy radzieckich. Powielają kalkę myślową, mówiącą o „żydowskim bolszewizmie”. Włącza się prześladowczy stereotyp, Żyd zarazem funkcjonuje jako erzac rzeczywistego (domniemanego) winnego. W akcie dewastacji Cmentarza Mauzoleum Żołnierzy Radzieckich z 2017 roku wyraźnie daje o sobie znać mechanizm przeniesienia agresji; czerwone stopy odciśnięte na „czerwonym” pomniku zostają przypisane „żydowskiemu kozłowi ofiarnemu” (metafory „kozłów ofiarnych na nieustającym dyżurze" użył kiedyś w odniesieniu do Żydów Zygmunt Bauman) $)^{45}$.

Cmentarze wydziela się po to, aby utrwalać pamięć o zmarłych, ale przecież również po to, byśmy mogli na co dzień uwolnić się od ciężaru pamiętania, ciążącą nam przeszłość pochować ${ }^{46}$.Zarazem jednak martwe ciała i groby - które wbrew powszechnemu mniemaniu wcale nie milczą - wykorzystuje się w bieżącej polityce, żeby programować (albo przeprogramować) życie przyszłych pokoleń ${ }^{47}$. Niektóre cmentarze - w tym właśnie nekropolie wojskowe - są, jak próbuję tu pokazać, upolitycznione w sposób szczególny ${ }^{48}$. $\mathrm{Z}$ miejsc wiecznego spoczynku zmieniają się co jakiś czas w miejsca, gdzie żyjący manifestują swoje sympatie i antypatie polityczne; odbywają się na ich terenie sądy nad historią i teraźniejszością. Niegdyś ciała zmarłych żołnierzy zawłaszczała ideologia komunistyczna. Obecnie, o czym świadczą hasła malowane przez wandali na mogiłach, używa się ich przeciw „postpeerelowskiej agenturze" działającej na szkodę Polski ${ }^{49}$.

Z. Bauman Wytłumaczyć niewytłumaczalne, w: Wokół „Strachu”. Dyskusja o książce Jana T. Grossa, red. M. Gądek, Znak, Kraków 2008, s. 209.

M. Napiórkowski Powstanie umarłych. Historia pamięci 1944-2014, Wydawnictwo Krytyki Politycznej, Warszawa 2016, s. 169-173.

Tamże, s. 89 .

Weźmy Cmentarz Powązkowski w Warszawie - miejsce pochówku wielu wybitnych Polaków oraz żołnierzy powstań narodowych. Napiórkowski analizuje w swojej książce m.in. polityczne wiece nad grobami.

Żeby skomplikować obraz, powiedzmy słów kilka na temat "wzmożenia mocarstwowego" w polityce Kremla. Putinowska Rosja troszczy się o dziedzictwo radzieckie. I wciąż chce mieć pod kontrolą ziemie, w które wsiąkła krew żołnierza radzieckiego. Próbom usuwania pomników komunistycznych w krajach byłego bloku socjalistycznego towarzyszą rytualne protesty Moskwy. Jak silne są imperialne sentymenty na Kremlu i jak łatwo mogą wezbrać ponad miarę, przypominają wydarzenia, do których doszło wiosną 2007 roku w Estonii, kiedy władze Tallina zdecydowały o przeniesieniu pomnika "wyzwolicieli miasta” (tzw. Brązowego żołnierza) na cmentarz; wiązało 
Widać wyraźnie, że spory wokół cmentarzy Armii Czerwonej uwarunkowane są postautorytarną (posttotalitarną) i de facto postkolonialną kondycją współczesnej Polski. Kondycja ta skłania do postawienia pytania: jak poradzić sobie z komunistycznym piętnem odciśniętym w krajobrazie?

Szukając odpowiedzi, przyjrzyjmy się fotografiom Wojciecha Wilczyka. W 2003 roku artysta odwiedził cmentarz komunalny w Starym Chorzowie. $\mathrm{Z}$ tamtejszej nekropolii wojskowej otwierał się widok na ruiny Huty Kościuszko, którą przyszedł sfotografować: „Pomyślałem wówczas, że być może sfotografowanie wojennych cmentarzy Armii Czerwonej mogłoby być interesującym wizualnie przedsięwzięciem [... ${ }^{50}$. Do pomysłu fotograf powrócił ponad dziesięć lat później; najwięcej zdjęć powstało na przełomie 2017 i 2018 roku, wciąż powstają nowe.

Na fotografiach widzimy przede wszystkim mogiły i pomniki cmentarne, ale trafiają się również pomniki niezwiązane z nekropoliami. Wilczyk sfotografował m.in. bardzo ciekawy architektonicznie pomnik w Mikolinie (woj. opolskie), poświęcony pamięci żołnierzy Pierwszego Ukraińskiego Frontu Armii Czerwonej, poległych w styczniu 1945 roku, podczas forsowania Odry. Ten zwieńczony czerwoną gwiazdą obelisk - dopiero co poddany gruntownym pracom konserwatorskim i odsłonięty po remoncie w czerwcu 2017 roku - zdobią dzioby łodzi; nad jedną z nich umieszczono teraz krzyż prawosławny. Znowelizowana ustawa o zakazie propagowania komunizmu nakazuje usunięcie monumentu (koszty miałaby ponieść gmina Lewin Brzeski). Mieszkańcy są jednak temu przeciwni. W chwili, gdy piszę ten tekst, podano do wiadomości, że na nadzwyczajnym posiedzeniu w lewińskim ratuszu radni zagłosowali przeciwko rozbiórce; w sprawę będzie musiał zaangażować się wojewoda opolski ${ }^{51}$.

się to z ekshumacją szczątków żołnierzy pochowanych u stóp monumentu. Początkowo pokojowe protesty rosyjskiej mniejszości narodowej przerodziły się w zamieszki; zginęła jedna osoba, a kilkadziesiąt zostało rannych. Awantura o radziecki pomnik spowodowała również odpalenie cyberbomby; doszło do ataków hakerskich - wiele wskazuje na to, że inspirowanych przez Kreml (unieruchomiono strony ministerstw, partii politycznych, policji, banków); ich największe nasilenie przypadło na 9 maja (Dzień Zwycięstwa) - żeby było jasne „kto (nadal) rządzi w regionie”. Zob. J. Jalonen Dni, które wstrzq̨snęły Estoniq̨, przeł. P. Bukalska, „Tygodnik Powszechny”, www. tygodnikpowszechny.pl/dni-ktore-wstrzasnely-estonia-136573 (1.04.2018). W. Wilczyk Odwiedzając nekropolie Armii Czerwonej, „Herito” 2017 nr 29, s. 140.

51 A. Kiereta Radni przeciwko wyburzeniu pomnika ku czci Armii Czerwonej, TVP3 Opole, 13 marca 2018, https://opole.tvp.pl/36377782/radni-przeciwko-wyburzeniu-pomnika-ku-czci-armiiczerwonej-w-mikolinie (1.03.2018). 
Na innym zdjęciu zrobionym przez Wilczyka widzimy zrujnowany pomnik stojący na peryferiach Głubczyc (woj. opolskie) - postawiony na miejscu prowizorycznego cmentarza żołnierzy radzieckich, którzy w 1945 roku zginęli w walkach o miasto; niedługo po wojnie ich ciała ekshumowano i przeniesiono na cmentarz w Kędzierzynie Koźlu. Obelisk z czerwoną gwiazdą budzi kontrowersje. Jedni chcą go burzyć - powołują się na ustawę o zakazie propagowania komunizmu - wskazują, że nie jest to pomnik cmentarny. Inni chcą go remontować - powołują się na tę samą ustawę - zaznaczają, że to pomnik upamiętniający poległych, pamiątka po nekropolii wojennej.

Fotografie Wilczyka traktować można jako komentarz do wzmożonej aktywności rozrachunkowej, dającej się odczuć od wyborów wygranych przez PiS w 2015 roku:

Niewątpliwie - pisze fotograf - sierp i młot oraz czerwona gwiazda są emblematami totalitarnego państwa o komunistycznym ustroju, nieistniejącego od ponad ćwierćwiecza Związku Socjalistycznych Republik Radzieckich, utrzymującego w sferze swoich wpływów satelicką Polską Rzeczpospolitą Ludową (płacącą ogromny ekonomiczny haracz), lecz może warto zachować te znaki na cmentarnych pomnikach jako swoiste memento dla obywateli tego kraju oraz dla polityków o autorytarnych skłonnościach ${ }^{52}$

Szeregowi żołnierze, zaznacza fotograf, „często stracili życie wskutek bezwzględnej taktyki swoich dowódców, którzy podczas operacji wojennych nie przejmowali się zbytnio - by tak to eufemistycznie określić - stratami ludzkimi w podległych im oddziałach"53.

Wojskowe nekropolie są świadectwem okrucieństwa i absurdu wojny oraz oddania ideologii; żołnierz umiera za sprawę, którą wziął - nie miał innego wyjścia - za swoją (Karol Marks powiedziałby o fałszywej świadomości), ale martwy żołnierz nadal może służyć ideologii, co fotograf próbuje pokazać. Obiekty cmentarne interesują go, ponieważ przemawiają (tradycja architekture parlante), albo, używając języka Louisa Althussera ${ }^{54}$, interpelują, czy raczej ideologia za ich pośrednictwem interpeluje, odwiedzających nekropolię. To,

\footnotetext{
52 W. Wilczyk Odwiedzając..., s. 144.

53 Tamże, s. 143.

54 L. Althusser Ideologia i aparaty ideologiczne państwa, przeł. A. Staroń, Studencie Koło Filozofii Marksistowskiej UW, Warszawa 2006.
} 
inaczej rzecz ujmując, obiekty, które wysyłają sygnał ideologiczny, wypytując nas o tożsamość. Na ile czujemy się adresatami tej interpelacji?

Zdjęcia Wilczyka nie mają charakteru inwentaryzacyjnego. To część projektu Architektura symetryczna, złożonego $\mathrm{z}$ fotografii przedstawiających różne realizacje architektoniczne, które wyróżniają się - za sprawą prostoty użytych form - monumentalnością, a zarazem komunikujących treści symboliczne.

Fotograf kieruje naszą uwagę na dominanty architektoniczno-rzeźbiarskie, czyli najważniejsze akcenty plastyczne przestrzeni cmentarnych: reprezentacyjne bramy wjazdowe, mauzolea, rzeźby monumentalne, gloriety, obeliski itp. Mogiły żołnierzy - oznaczone czerwoną gwiazdą - oglądamy zazwyczaj w planie ogólnym.

Na zdjęciach znalazło się to, co wyróżnia radzieckie cmentarze pod względem estetyki i ikonografii.

Rzuca się w oczy obecność symboliki wojennej - oglądamy pomniki z figurami uzbrojonych żołnierzy, a także czołgi i armaty przeciwpancerne ustawione przy bramach wejściowych (brama cmentarza oficerów Armii Radzieckiej we Wrocławiu, brama cmentarza wojennego żołnierzy Armii Radzieckiej w Sandomierzu). Gdy patrzy się na te zdjęcia, nie widzi się malowniczych miejsc kontemplacji żołnierskiego cierpienia. Fotograf pokazuje raczej, że nekropolie Armii Czerwonej przynależą do kultury wojny i komunikują przede wszystkim treści polityczne. Poległych czci się, redukując ich żywot do identycznych, niczym nie różniących się od siebie kamieni albo tablic; cechy formalne tej przestrzeni określa narracja o honorze przynależności wygaszającym roszczenia związane z interesem własnym ${ }^{55}$. Centrum pola semantycznego zajmują komunistyczne symbole. Żołnierska ofiara legitymizuje ideologię. Na zdjęciach Wilczyka widać to bardzo dobrze - mamy tu do czynienia z fotografią barwną, przez co znaki sierpa i młota oraz gwiazdy czerwonej, często malowane na kolorowo, tym bardziej przyciągają wzrok.

Sfotografowane obiekty poddają się klasyfikacji typologicznej: obeliski, kolumny, mauzolea, gloriety, bramy cmentarne. Dostajemy przegląd form, ewoluujących od czasów starożytnych, które stały się symbolami wiecznej chwały i kulturowymi uniwersaliami ${ }^{56}$; np. architektura mauzoleum żołnierzy radzieckich i polskich na cmentarzu św. Marcina w Jarocinie została zainspirowana formą klasycznej greckiej świątyni. Przede wszystkim jednak

55 Por. M. Miller Ogród jako dzieło sztuki, przeł. P. Mróz, A. Warmiński, w: Estetyka wświecie. Wybór tekstów, t. 5, red. M. Gołaszewska, Wydawnictwo U), Kraków 1997, s. 120-121.

56 Por. D. Czarnecka „Pomniki wdzięczności”..., s. 98. 
zgrupowanie podobnych obiektów daje możliwość rozpoznania powtarzalnych elementów artykulacji architektonicznej i rzeźbiarskiej, służących ideologicznej perswazji. Zdjęcia pokazują, że charakterystyczna dla wojskowych założeń cmentarnych jest hierarchiczna organizacja przestrzeni. Strzeliste obeliski i potężne mauzolea stanowią punkty orientacyjne, które nadają przestrzeni uporządkowaną strukturę oraz właściwy sens pozostałym elementom cmentarza, ustawionym względem dominant w porządku malejącym. Perspektywy widokowe, wychodzące na najważniejsze obiekty cmentarza, ułatwiają „orientację ideologiczną”. Małą architekturę wyróżnia: surowa, geometryczna forma, minimalizm ornamentalny, militarystyczna symbolika, typizacja figur pomnikowych.

Łącząc ducha geometrii z wartościami moralnymi i politycznymi, pojęciami takimi jak odwaga, siła, niewzruszoność, twórcy nekropolii wojskowych budują, jak pokazuje Wilczyk, wzniosłość estetyczną. Widzimy, że w przestrzeni cmentarzy wojskowych odzwierciedla się to, co polityczne, oraz to, co oniryczne - jedno i drugie ma wpływ na efekt wizualny całości. Nekropolie wojskowe, wnioskujmy, to miraże utopii estetycznej w służbie pamięci i propagandy (komunistycznej) - utopia ta opiera się na regularności, powtarzalności elementów i symetrii kompozycyjnej. Stąd zresztą tytuł całego projektu: Architektura symetryczna.

Zdjęcia dokumentują ponadto stan zachowania cmentarzy Armii Czerwonej. Pokazują również, że ludzie pamiętają. Spora część fotografii powstała blisko dnia Wszystkich Świętych. Na grobach i pod pomnikami widać wypalone znicze i kwiaty ${ }^{57}$. Mogiły są odwiedzane przez członków rodzin pochowanych, z Rosji, Ukrainy, Białorusi, ale lampki palą też Polacy (np. w Olkuszu, gdzie mieszkam i gdzie również trafił fotograf, idzie się zapalić lampkę żołnierzom pochowanym na cmentarzu komunalnym: żołnierzom polskim - poległym w czasie I wojny światowej, i radzieckim, których kwatera znajduje się tuż obok).

Fotografie nekropolii Armii Czerwonej zaliczyć należy do „rewizjonistycznych pejzaży"Wilczyka - pejzażystą-rewizjonistą nazywa go Adam Mazur ${ }^{58}$. Rewizjonistycznych dlatego, że przedstawiają to, co nie przystaje do potocznych wyobrażeń o „naszej polskiej ziemi”, to, czego nadmiernie się nie eksponuje. Fotografa interesują widoki, które sprawiają kłopot, przypominające

57 W. Wilczyk Odwiedzajq̨c..., s. 143-144.

58 A. Mazur Święta Wojna, w: Święta Wojna (2009-2014)/Wojciech Wilczyk, Atlas Sztuki, Łódź-Wydawnictwo Karakter, Kraków 2014, s. 21. 
o powikłanej historii kraju oraz splątanych ścieżkach kultur określających jego specyfikę, miejsca obciążone historycznie, ale takie, których historia z pamięci wylatuje, i choć znajdują się na widoku, łatwo je przeoczyć, albo przemieszczają się na obrzeża pamięci - pamiętają o nich (już) nieliczni, są też tacy, którzy woleliby skazać je na zapomnienie. Inaczej rzecz ujmując, zdjęcia Wilczyka odsłaniają ukrytą w otaczającej nas przestrzeni niewygodną pamięć przeszłości, a co za tym idzie, uwidaczniają polifoniczność polskiego pejzażu ${ }^{59}$. Wartość nekropolii Armii Czerwonej, zdaje się mówić Wilczyk, bierze się z tego, że to świadectwa wielowymiarowego życia społeczeństwa, $\mathrm{w}$ tym również jego nieukończonego zmagania się z widmem komunizmu.

Reakcja artysty na rzeczywistość postautorytarną, w jakiej przyszło nam funkcjonować, jest też poniekąd „muzealnicza”. Fotograf kolekcjonuje widoki, które mają, jak sugeruje, wartość antropologiczną. Stąd zaś można wyciągnąć taki wniosek, że włącza „kłopotliwe dziedzictwo" ${ }^{\text {"S0 }}$ do kolekcji kultury. W ten

59 Bardzo dobrze widać to też w cyklu Niewinne oko nie istnieje. Fotograf pokazuje nam bożnice iżydowskie domy modlitwy, które zmieniły swoją funkcję; zostały przekształcone w biblioteki, supermarkety, warsztaty, magazyny itp. To fotograficzny zapis tego, co „jako codzienne staje się niewidoczne" (jak pisze Adam Mazur) i czego uwidocznienie budzi, jak sądzę, koszmary „prześnionej rewolucji”, by użyć sformułowania Andrzeja Ledera (Prześniona rewolucja. Ćwiczenie z logiki historycznej, Wydawnictwo Krytyki Politycznej, Warszawa 2014). Sfotografowane przez Wilczyka budynki przypominają, mówiąc Lederem, o transpasywnym udziale Polaków w przemocy wobec Żydów. Według autora Prześnionej rewolucji, stosunek dużej części społeczeństwa polskiego do hitlerowskiego planu rozwiązania kwestii żydowskiej wyznaczał antysemityzm. Wprawdzie aktywny udział tego społeczeństwa w mordowaniu polskich Żydów był niewielki, ale ludność nieżydowska skorzystała ze skutków działań niemieckiego okupanta, doświadczyła spełnienia skrytych pragnień i zajęła miejsce po Żydach. Zagłada mieszczaństwa żydowskiego - zgodnie z rozpoznaniami Ledera - stworzyła warunki umożliwiające powstanie nowej klasy średniej, polskiej w sensie etnicznym. Mało tego, mówi Leder, transpasywne uczestnictwo w wypieraniu Żydów ze wspólnoty państwowej i narodowej wywarło wpływ na powojenne postawy Polaków (prawda o genealogii polskiej klasy średniej jest wypierana, jej zapoznanie - zaprzeczanie odpowiedzialności za zło - sprzyja postawom antysemickim). Wilczyk pokazuje, że ukształtowało ono również powojenną ikonosferę. Oglądając Niewinne oko nie istnieje, nie sposób oprzeć się wrażeniu, że społeczeństwo nie bardzo stara się zachować nośniki pamięci o polskich Żydach - właśnie dlatego, jeśli zgodzić się z Lederem, że niemiło przypominają one o własnych „zaniechaniach" (mówiąc eufemistycznie). Biorąc pod uwagę, że Żydzi przez wieki współtworzyli kulturę polską, można mówić o wyparciu się części własnego dziedzictwa - w efekcie powstaje uproszczony obraz tego, co polskie. Treści, jakie przekazuje stworzony przez Wilczyka atlas synagog i domów modlitwy, uderzają choćby w stereotyp Polaka-katolika. Zrazem fotografie te uświadamiają, że w wielu polskich miasteczkach pamięć o polskich Żydach jest nie tyle wymazana, co zamrożona.

60 J.E. Tunbridge, G.J. Ashworth Dissonant Heritage. The Management of the Past as a Resource in Conflict, John Wiley \& Sons, Chichester, New York 1996. 
sposób je spożytkowuje i doprowadza do jego „umojenia” (wedle określenia Jacka Purchli) ${ }^{61}$. Dlaczego znaleziona na cmentarzu radzieckim „forma autorytarna" jest (również) nasza? Dlaczego kłopotliwe dziedzictwo to nasze dziedzictwo? Fotografie Wilczyka podpowiadają, że dlatego jest ono nasze, gdyż zwraca się do nas, gdyż nam, nie komu innemu, sprawia kłopot (za Althusserem: interpelowany zawsze rozpoznaje, że jest interpelowany, „[...] interpelacja praktycznie zawsze trafia na właściwego osobnika"62), a także ze względu na archetypiczny - transhistoryczny, a przez to uniwersalny - kod formalny właściwy sztuce na usługach władzy/ideologii.

Radzieckie nekropolie wojskowe - w świetle projektu Architektura symetryczna - to nie tylko „miejsca pamięci” o żołnierzach Armii Czerwonej, lecz także „miejsca wspominania” własnej historii. Dodajmy, że właśnie jako „miejsca wspominania” Andrzej Szpociński proponuje tłumaczyć pojęcie Pierre'a Nory lieux de mémoire ${ }^{63}$ - w ten sposób wydobywa całą pojemnością semantyczną tego określenia ${ }^{64}$. Lieux de mémoire mają nam wiele do powiedzenia o przeszłości i o nas samych. Fotograf zachęca do namysłu nad miejscem, w którym żyjemy, dostarcza ono bowiem wskazówek nieumożliwiających zrozumienie tego, kim jesteśmy, przede wszystkim urządzenia dzisiejszego życia społecznego.

Rewizjonistyczne pejzaże Wilczyka uwypuklają również - aby bliżej określić charakter tego fenomenu, znów moglibyśmy odwołać się do Szpocińskiego - "przestrzenny charakter współczesnej kultury" - ma o nim świadczyć zarówno rosnąca popularność badań nad "miejscami pamięci”, jak i praktyki ich pokazywania. Szpociński zwraca uwagę na nowy sposób funkcjonowania lieux de mémoire, związany z postępującym procesem „wizualizacji kultury historycznej”; autor rozumie przez to: „dominację wrażeń wzrokowych w procesach transmisji i percepcji przeszłości". Rację badaczowi przyznawszy, tak to więc ujmę: fotografie Wilczyka pokazują „ "historyczne podłoże”, które „wywiera wpływ na zachowania aktualnie żyjących pokoleń”. To „historyczne podłoże” (określenie „podłoże” należy tu rozumieć przestrzennie - jako to, co wystawione na widok publiczny, co jednak wypada

61 Kwestia dojrzałości. Z profesorem Jackiem Purchlą rozmawia Łukasz Galusek, „Herito” 2017 nr 29, S. $14,16$.

63 Zob. P. Nora Czas pamięci, przeł. W. Dłuski, ,Res Publica Nowa” 2001 nr 4; P. Nora Między pamięciq̨ i historiq̨: Les lieux de Mémoire, "Tytuł roboczy: Archiwum” 2009 nr 2.

64 A. Szpociński Miejsca pamięci (lieux de mémoire), „Teksty Drugie” 2008 nr 4, s. 12. 
poza obręb uwagi większości) jest obecnie, jak podkreśla socjolog, ostentacyjnie komunikowane przez praktyków kultury ${ }^{65}$. Na koniec więc powiedzmy, że jest komunikowane zarówno dlatego, że łączy, jak i dlatego, że dzieli tych, którzy z niego wyrośli.

\section{Abstract}

\section{Patrycja Cembrzyńska}

INDEPENDENT SCHOLAR

The Resistance of Memory and Photographs of Historical Culture: Red Army Cemeteries

Polish laws prohibiting the promotion of communism (Dz. U. Journal of Laws 2016 no. 744, as well as 2017 nos 1389 and 2495) reawakened controversies on Red Army monuments and memorials on Polish territory and their belonging to the nation's cultural heritage. To explore this troublesome heritage Cembrzyńska uses the Red Army's military cemeteries as an example. She examines their role in communist propaganda and outlines the post-1989 debates concerning memorial sites dedicated to Soviet soldiers. She concludes by exploring Wojciech Wilczyk's photographs of Red Army cemeteries in his series "Architektura symetryczna" [Symmetrical Architecture], focusing on architectural and sculptural elements that articulate an intention of ideological persuasion.

\section{Keywords}

military cemeteries of World War II, history, communist propaganda, memorial sites, lieux de mémoire, cemetery

65 Tamże, s. 11-20. 